Boise State University

ScholarWorks

Literacy, Language, and Culture Faculty

Publications and Presentations

Department of Literacy, Language, and Culture

4-2013

\title{
Trapped in a Cycle of Low Expectations: An Exploration of High School Seniors' Perspectives About Academic Reading
}

\author{
Diana S. Hooley \\ Idaho State University \\ Lee Ann Tysseling \\ Boise State University \\ Beverly Ray \\ Idaho State University
}

From The High School Journal, Vol. 96(4), 321-338. Copyright @ 2013 by the University of North Carolina Press.

Used by permission of the publisher. doi: 10.1353/hsj.2013.0018 


\title{
Trapped in a Cycle of Low Expectations: An Exploration of High School Seniors' Perspectives About Academic Reading
}

\author{
Diana S. Hooley \\ Idaho State University \\ hooldian@isu.edu \\ Lee Ann Tysseling \\ Boise State University \\ ltysseling@boisestate.edu \\ Beverly Ray \\ Idaho State University \\ raybeve@isu.edu
}

\begin{abstract}
Reports show that the reading proficiency scores for 17-year-olds have stagnated over the past several decades. In this study, the authors explored older students' academic reading perceptions that might suggest links to proficiency. What do high school seniors really think about class reading? Do they understand what they read? How do they view teacher support for content reading? A quarter of the senior class of one mid-sized high school responded to open-ended questions such as these as well as a Likert-style reading attitude survey. Additionally, the teachers of the student study sample were interviewed about their students' reading behaviors and attitudes. Data revealed that these seniors largely felt confident in their class reading abilities despite the fact that most said they did not do much reading either for school or recreationally. Seniors also reported a lower tolerance for reading long periods of time and showed little preference for reading informational texts. Yet most participants planned to go to college and felt positively about the challenges presented by college-level reading. Student and teacher reports suggested both parties may be locked in a reciprocating cycle of low reading expectations that maintain student non-reading behaviors and unrealistic ideas about the skill level necessary for informational reading comprehension.
\end{abstract}

With increasing demands for higher levels of literacy and the national focus on the Common Core standards, students' critical reading of informational texts has moved front and center as an education and curriculum issue. However, despite such mandates, the reading proficiency scores for high school seniors dropped again this year according to the SAT report on college and career readiness (The SAT Report, 2012). The report revealed that the graduating class of 2012 scored lower in critical reading than in 2011, indicating a downward trend as the past several years of students scored four points lower than in 2008. The 2011 ACT reading benchmark report also showed no improvement in reading scores since the previous year with only about 
half of students (52\%) at reading benchmarks set for college readiness (ACT College and Career Readiness Report, 2011). The findings from both reports align with the National Assessment of Educational Progress (NAEP) long-term trend report, which showed that 17-year-olds' reading proficiency has remained stagnant over the past several decades (The Nation's Report Card, 2011).

Although we know high school students' reading proficiency is a concern for the educational community at large, do students and their content teachers see reading proficiency as a problem? What do they really think of class reading and reading instruction? What is the connection between academic reading attitudes and proficiency for older students? These are some of the questions we investigated in this exploratory study. High school seniors in their American Government class responded to two measures: open-ended questions and a survey about class reading. Their three government teachers were interviewed about class reading. Although previous content reading research has focused on teacher instruction or the reading attitudes of younger students, this study examined older students' attitudes and perceptions of academic reading as they readied themselves for college and/or careers.

\section{Literature Review}

Reading Expectations for Older Students

The Carnegie Foundation report entitled Reading in the Disciplines: The Challenge of Adolescent Literacy (Lee \& Spratley, 2010) discussed the complex content area reading processes and skills that students are expected to master on their path to reading proficiency. The authors noted that reading comprehension is a result of dynamic interactions among knowledge, strategies, goals and dispositions of students. Further, they stated that although various disciplines require specialized vocabulary and reading comprehension strategies, there are certain generic reading strategies across the disciplines, such as pre-reading, questioning the text, and predicting, that lead students to become more proficient disciplinary readers.

Other research highlights findings related to older student achievement specifically in informational kinds of reading. As students age, their success or failure in school is closely tied to their ability to understand informational texts (Irvin, Buehl, \& Klemp, 2007; Kamil, 2003). However, according to international achievement tests, U.S. students do worse at reading expository texts than they do at reading literary texts (Mullis, Martin, Kennedy, \& Foy, 2007). This may stem from what many consider a persistent imbalance in student exposure to such texts in school reading programs (Moss \& Newton, 2002). David Coleman, chief architect of the Common Core Standards (CCS), discussed the connection between NAEP testing, reading proficiency results for adolescents, and informational literacy, indicating educators need to focus more on teaching students to read informational texts to improve test performance that measure proficiency (Coleman, 2011). Since much of the reading done in schools is narrative, Irvin et al. (2007) reported concern over the mismatch between prior student reading history and expository reading expectations for older students.

\section{The Link Between Student Reading Attitudes and Achievement}

Research reveals that positive attitudes about school and academics are related to school success. McCoach and Siegle (2001) compared the attitudes of high- and low-achieving adolescents across several factors and found that "academic selfperception" was one of two subscales that predicted achievement status correctly over $86 \%$ of the time (p. 74). In other words, how students feel about their own skills and proficiencies in an academic area is related to their achievement in that 
area. In reading, positive attitudes and a sense of self-efficacy have been linked to achievement as well (Bandura, 1986; Guthrie, McRae, \& Klauda, 2007; Vacca, 2006). Vacca (2006) commented that students can read potentially difficult texts if they believe they can. He wrote: "When students feel certain that they can master the material they are facing, even those students for whom reading rarely comes smoothly, stand a better chance at achieving that mastery" (p. 59).

However, student academic attitudes can become overinflated, and such over-estimation of ability and skill level can present a mitigating factor for the positive attitude effects on reading achievement (Dunning, Heath, \& Suls, 2004). Students without good judgment of their own skills and abilities are hobbled meta-cognitively, susceptible to a distorted vision of what is required to learn. Simpson and Nist (2003) discussed the literature related to student misperceptions of college level reading: "Most college freshmen believe learning is simple, can be accomplished quickly, and that knowledge and learning occur when someone else does something to you'” (p. 158). Additionally, less competent students are often even poorer judges of their own academic performance (Hacker, Bol, Horgan, \& Rakow, 2000). Thus, it is important that teachers hold students accountable for their reading and make academic expectations clear. Without a good understanding of the skills necessary to do critical informational reading, the veneer of utility becomes a main motivating factor: students read enough to pass their class and ensure they graduate (Mitchell \& Ley, 1996).

\section{The Link Between Student Reading Attitudes and Teacher Instruction}

In order for students to see reading as a valuable and important activity there must be a supportive classroom context (Duke \& Pearson, 2002; Irvin, Buehl \& Klemp, 2007; Sweet, Guthrie, \& Ng, 1998). If teachers do not have expectations for classroom reading, a message can be transmitted that reading is a less important instructional activity (Birchfield \& Sappington, 2000; Rieck, 1977). However, past research suggests that reading is not deemed a high priority in the secondary curriculum (Donahue, 2003; O’Brien, Stewart, \& Moje, 1995). Teachers who have limited investment in class reading often are reliant on a single textbook for instruction that can be either uninteresting or written above grade level (Allington, 2002; Daniels \& Zemelman, 2004; Wilhelm, 2007). Additionally, the dual limitations of limited class time and the necessity of covering mandated curriculum standards have both impacted content teachers' ability to support class reading (Fisher, 2004; Ness, 2007; Schoenbach, Braunger, Greenleaf, \& Litman, 2003). Ness (2007) collected data in eight middle and high school science and social studies classrooms and concluded students experienced little direct exposure to print in the classes she observed.

Largely due to time constrictions, secondary educators have developed strategies to cover reading requirements more efficiently. Many teachers explain via lectures what students were supposed to read, which gives students even less incentive to do reading assignments themselves and little practice at navigating through difficult texts (Alvermann \& Moore, 1991; Alvermann, Phelps, \& Ridgeway, 2007; Irvin, Buehl, \& Klemp, 2007). Another standard but widely castigated reading instruction practice at the secondary level is called "ping pong" reading (Irvin et al., 2007 , p. 20). This reading strategy asks students to go back and forth between a class text reading and a worksheet that requires students to cherry-pick bits of information from the text. The point then, is not to have students actually read the text, but rather to locate disconnected pieces of content information.

Teacher reading instruction can also be influenced by student behaviors. Part of the reason for low reading expectations is that generalized student resistance to class 
reading remains both well known and widespread (Lesley, Watson, \& Elliot, 2007). Research suggests adolescents may be resistant to informational kinds of reading for a number of reasons, including potential delays in reading maturation, inability to read for extended lengths of times, and limited experience with expository reading as opposed to narrative reading, for which a foundation has been built through engagement during their younger years (Brozo \& Sutton Flynt, 2008; Jacobs, 2008; Schoenbach \& Greenleaf, 2009).

\section{Theoretical Framework}

An understanding of Bandura's social cognitive theory (1986) informs our interest in high school seniors' perceptions of academic reading. Bandura's work assists us in the conceptualization of individual students as potentially self-organizing, proactive, self-reflecting, and self-regulating learners. Thus, we acknowledge that selfefficacy, positive self-beliefs, and attitudes can all play a role in student learning and reading success. Older students have demonstrated that if they view the information presented to them in their reading as authentic and useful in meeting their goals, they can and would meet the challenge of more mature, informational reading (Kamil, 2003; Shanahan, 2004; The Council Chronicle, 2007).

As part of his social cognitive construct, Bandura (1978) also theorized about the power of "self-influences," that the learner's intrinsic motivations become engaged in learning systems in both active and reactive ways. Thus, given an educational context, "the self" not only responds but also has the power to become a causal force, effectively changing the learning environment. Thus, students or teachers can either instigate or reflect attitudes that in turn become drivers of behavior in the classroom setting. Bandura labeled this reciprocating mechanism of reinforcing attitudes and behaviors reciprocal determinism. Bandura's transactive, motivational framework provided a theoretical background for this bi-directional study, looking at student perceptions of their class reading from both the student and teacher viewpoints.

\section{Method}

Our study took place in a semi-urban high school located in the Intermountain Western United States. Though the majority of students at the study school identified themselves as White, there was $14.32 \%$ identifying as Hispanic. Additionally, $32.17 \%$ of students were categorized as low-income learners. Three high school government teachers, including one student teacher, agreed to participate in this study and allowed the researchers to poll student perceptions in eight class sections. Thus, these students represent a convenience sampling (Creswell, 1994). We chose government classes because two of the authors had background interest and previous K-12 experience teaching in the social studies area. Additionally, Common Core Standards set requirements not only for English language arts (ELA) but also for literacy in history/social studies, science, and technical subjects (Common Core Standards, 2012). Slightly more than a quarter of the senior class $(n=64)$ was included in our sample. Fifty-five of the 64 students $(87 \%)$ indicated they were college bound. Students enrolled in selected, intact classrooms taught by the three teachers were informed of the nature of the study and agreed to participate voluntarily.

Three measures were conducted in this study in order to gain a broader view of senior-level academic reading attitudes. During the nine-week study, students were given reading response worksheets with questions related to class reading assignments as well as reading attitude questions targeted to expose student perceptions of their own reading practice and teacher reading instruction. Text-reading periods occurred about twice a week in government class given the block scheduling of classes. 
Content assessment for these classes was predicated on textbook units and chapters, thus students were asked to read their textbook as part of the preparation for final summative assessments. As a second measure, students also completed a reading attitude survey before the study began. Finally, teachers were interviewed about student reading at the end of the study. All data were collected in the spring semester of the student participants' graduating year.

\section{Measures}

\section{Reading Attitude Questions}

After each class session, participants were given reading response worksheets. The worksheets were modifications of suggested reading response strategies developed by Wilhelm (2007) and Tovani (2004). Typically the reading response worksheets began with two or three question prompts, either general enough to apply to any kind of reading or more targeted to the kind of informational or expository text reading students had done. Some of the reading response worksheets investigated interest or engagement, while others queried students on their reading comprehension. A few utilized well-known reading strategies such as KWL. Others relied on graphic organizers like Venn diagrams.

At the bottom of each worksheet students were asked general attitude questions about reading for class. They wrote about their own reading practices and their perceptions of teacher support and instruction in content reading. They also responded to questions about college reading. They were asked to project how they would deal with college reading assignments. These open-ended questions were designed to expand student discussion beyond the survey's civics content area to illicit information regarding students' experiences of class reading across the curriculum. See Appendix A, Table 1 for a list of the attitude questions found on reading response handouts.

\section{Survey of Student Reading Attitudes}

Academic reading attitudes were assessed using a Likert-style survey. Some of the survey items were more general in nature while other items reflected content reading attitudes related to participants' American Government class and their class text, Magruders American Government (McClenaghan, 2007). Pearson Publishing House notes that Magruders is written near the $6^{\text {th }}$ grade reading level. For this survey we created thematic subsets using The National Council of Teachers of English (NCTE) recommendations for improving adolescent literacy (The Council Chronicle, 2007). According to the NCTE report, although students have learned basic reading and writing skills by the fourth grade, they still need to master specialized contentarea literacy, and attitudinal motivations were central ingredients in getting adolescents to meet these new literacy challenges. Their research points to basic elements of adolescent reading motivation and engagement: students' sense of self-efficacy as readers, a sense of ownership of what they read, and a variety of reading texts and formats that increase engagement (The Council Chronicle, 2007, pp. 3-5).

Thus, from the NCTE recommendations senior attitudes related to class reading were measured under four thematic subset areas: 1) reading identity (confidence), 2) reading choice/autonomy, 3) comprehension (efficacy), and 4) reading enjoyment in the content area. Students were able to respond to survey items at four levels: strongly disagree, disagree, agree, and strongly agree (Creswell, 1994). See Appendix A, Table 2 to view subset items, means, and validity statistics.

\section{Teacher Interviews}

The three participating American Government teachers were also interviewed poststudy. Two of these instructors, Instructor A and Instructor B, had taught in the social 
studies area for over 10 years. The third teacher, Instructor C, was a student teacher at the time under Instructor B's supervision. We decided to interview both the supervising teacher and his student teacher as both instructors shared instructional duties during the nine-week time period of this study.

We utilized the general interview guide approach. Although this is more structured than the informal conversational interview, it still presented us as interviewers quite a bit of flexibility in its composition. Thus, teachers were asked the same basic questions, but subsequent discussion around these questions may have been digressive. According to McNamara (2009), the strength of the general interview guide protocol is the ability of the researcher "to ensure that the same general areas of information are collected from each interviewee; this provides more focus than the conversational approach, but still allows a degree of freedom and adaptability in getting information from the interviewee" (Types of Interviews section, para. 1). Appendix B contains the list of interview questions.

\section{Results}

\section{Reading Attitude Questions}

Student responses to the reading attitude questions are shown in Appendix A, Table 1. The content of reading prompts was analyzed to identify emergent themes and then data was organized around those emergent themes. Following are summary statements from each question reflecting student responses and a sampling of students comments related to that question.

Students felt like they can meet the challenge of college-level reading but almost half said 20 minutes was too long. Although $87 \%$ of the sample responded that yes, they were going to college, many had different ideas about how they would deal with the rigors of college-level reading. About half of the students (56\%) responded with a great deal of confidence, saying they would try to read everything assigned because college was important. Of this number nearly one-third forecast a rigid selfdiscipline that was not in evidence in their reported reading practices elsewhere in the reading attitude questions. For example, one student's response embodied this approach: "I'll read what I'm assigned (in college), I just won't enjoy it and I'll force myself to stay tuned into the story." Other students commented in the same vein: "I may struggle with reading, but I am going to do what it takes to reach my goals." And said another student, "Just deal with it and read it." Eight students out of 64 mentioned, "skim reading." For example, one student wrote, "I've heard there is a ton of reading in college and 'skimming' through books is the best way, so I'll probably do that."

In lieu of the amount of academic reading necessary to succeed in college, students reported on length of time spent reading academic materials. Almost half of these seniors said that reading 20 minutes for class was too long (45\%). Those that thought 20 minutes were too long often commented that reading was boring. Twelve students responded more positively, stipulating that they wouldn't mind reading class materials for 20 minutes if the information was interesting and/or relevant to them. Two different students reported how fast time would go if the reading was fun or interesting, but one of these students added that reading for class was not fun. Another senior said reading for 20 minutes was "a decent amount."

High school seniors reported they do not do much academic or recreational reading. Slightly more than half of the students reported positively that they did at least some of the assigned class reading (54\%). Twelve of these students said they tried to do 
assigned reading without indicating whether or not it was an accomplished task, while other students appeared to hedge, making more noncommittal responses like "it depends" or "occasionally." Although the question did not directly ask for reading motives, several of the responses indicated that the motivation for doing class reading had little to do with interest and engagement and much to do with feeling responsible to do the reading. Said one student, "If it's for my grade, it's important." Another student responded: "Most of the time the tests we get are directly from what we are supposed to be reading."

Students also reported reading for school over their lifetime. Participants said they did less school reading as they aged. They were asked when, in their years of attending public school, grades 1-12, was a time they remembered doing the most reading. Only $24 \%$ of these students reported one of their high school years. Other responses varied, with 18 students out of the 64-student sample noting middle school grades 4-8 as a time when they read a lot. One student said, "I did (read books) up until the $7^{\text {th }}$ grade, but AR (Accelerated Reader) ruined it for me." Another student responded, "I've read my entire school [career], I've always loved literature and always will." In contrast, another student reported: "Yes, I read a lot in grades 5-9, but not really anymore."

On the survey, only $30 \%$ of the seniors reported preferences for informational kinds of reading over narrative reading. Yet when participants were asked about recreational reading the past four months, only a third could give us the name, author, or description of a book they had recently read. Two-thirds of the seniors admitted that they had read nothing recreationally during this time period. However, it should be noted that there is an inherent bias in this question. We asked for books students had read recreationally, either in print or electronically. We queried students about book reading in light of book formats, which encourage focus and sustained engagement over a period of time. Researchers have noted that it is important for adolescent readers to learn how to read for longer periods of time, to develop reading stamina (Schoenbach \& Greenleaf, 2009). Therefore, students may have recreationally browsed or read websites, blogs, magazine or newspaper articles either in print or online, unaccounted for in this question.

Students considered class reading important. A majority of students (64\%) agreed that reading for class was important. Answers from students suggest they are aware of an educational and/or societal expectation that in order to succeed academically you must learn to read. Also, students appeared to make the connections between reading, college, and career success. Some of the reasons participants gave for the importance of class reading had to do with personal growth expectations and the feeling that class reading was necessary to learn and helped them to do better in school. One student said, "(Reading is important) because that's how we achieve knowledge." Another responded, "Yes, it's important, it helps our minds grow and mature."

Seniors doubted their teachers expected them to do class reading, and reported teachers gave little time in class for reading and relied on a single textbook. When asked whether or not students had teachers with low reading assignment expectations, 54\% responded positively, writing that they doubted at least some of their teachers expected them to do their class reading. Forty-six percent of students in the group seemed unsure, but expressed hope about teacher reading expectations with many using qualifying phraseology like "probably" or "I think so." The expectation question in the questionnaire was a speculative one as the purpose was to uncover students' perceptions of teacher expectations. For example, one student 
responded with a very long (comparatively) thoughtful response about teacher reading expectations. His response:

Sometimes there are teachers who don't expect you to do the assigned reading because they don't really expect a lot out of you. If you show signs of being a slacker or not caring, then they have their expectations from you set really low. I think a lot of teachers give out assignments and hope that everyone does them, but they always have a pre-set expectancy of who's actually going to do it or not.

Largely, students did not appear to castigate their teachers for low reading expectations but appeared to place the blame on themselves. One student defended his teacher's pedagogical approach to reading: "I had a teacher teach U.S. History that didn't require any reading and it was a good way." However, not every student was so forgiving of teacher reading instruction practices, as per this student's comment: "Some teachers don't expect us to read-and if they don't expect me to read, that's their fault."

The participants in our study also reported by a larger negative margin that teachers did not give them time in class to read (74\%). Many qualified their general negative responses with "most don't" or "they say it's time to read while they take attendancebut we just goof off" or "my English teacher does at the end of the period sometimes, but none of my other teachers." One senior said, "Most teachers have lessons that don't require reading." Students said teachers largely expected them to do assigned reading at home and a couple of students noted that's why they didn't do it; they worked after school or had other activities they deemed more important.

Eighty-five percent of participants reported in the survey that they wanted choice in their reading over a single classroom textbook. However, graduating seniors in this investigation still reported their content teachers relied on one class text to teach their courses. When asked whether teachers encouraged students to read books on their class subject other than the textbook, $84 \%$ responded negatively. One student said: "No (non-text) reading really... not even my history or English teachers pushed me to read other books." Another student wrote: "Librarians have tried to get me to read other books. They always tell me to read real nonfiction stuff, facts about life and how it is." This student summed up several student comments revealing teacher dependence on texts: "No. They always tell us to read what is in the textbook and that will teach you everything you need to know."

\section{Reading Attitude Survey}

Although survey results are presented under thematic subset headings, findings can be viewed from the standpoint of individual item responses provided it is understood that each item provides a discrete and limited approximation of a latent continuous variable (Clason \& Dormody, 1994).

Subsets: Reading Identity and Reading Autonomy. Senior participants in these subsets reported they did not like to read and preferred their instructors tell them what is important in the lesson reading rather than reading themselves. Over half of participants $(58 \%)$ said they did not like to read, in general. Also, in spite of students' expression of confidence in their own reading abilities, $80 \%$ preferred to rely on teacher lectures rather than actually doing the reading themselves. The inference embedded in this survey item is that students have experienced teachers lecturing over assigned reading, which was apparently validated and preferred by a large majority of these seniors. This item may not only indicate a lack of student academic 
reading motivation, but also hints at causality: why should students read academic texts when their teachers will lecture over the reading? One interesting response that did not align with the rest of the survey findings was that $58 \%$ of students agreed they would not understand the lesson if reading was the only way to learn it. Again, we felt this item said less about student comprehension ability (due to a great deal of contradictory responses in other parts of the survey) and more about students' desire to have the task of reading mitigated, which would again point to possible reading motivation problems influenced perhaps by teacher instruction.

Subset: Reading Comprehension. Largely, student responses indicated they felt they understood what they read in class. They reported on three different survey items comprehension of the reading for American Government class. Seventy percent said if they do the lesson reading they feel confident they "get" what the lesson is about. Another $73 \%$ acknowledged they understood the vocabulary used in the textbook. Only $24 \%$ found the books and materials in their class hard to read. One caveat to these findings was that nearly three-quarters of participants acknowledged that if they knew the meaning of more words in the textbook they could read it better. In light of the other responses under this subset we decided that this response had more to do with students simply acknowledging that vocabulary knowledge is part of comprehension as opposed to suggesting that the vocabulary in their government texts was too difficult. However, it should be noted that although students largely reported they understood what they read for class, whether they actually did or not is unknown.

Subset: Content Reading Enjoyment. The most definitive subset average of the survey was Content Reading Enjoyment with most students reporting a dislike of American Government content reading. Responses under this subset clearly indicated these high school seniors wanted reading choices in their classes and preferred narrative over informational kinds of reading. Eighty-five percent (85\%) of seniors responded that they wanted reading choice over a single textbook. This was the highest percent of agreement in the entire survey on any individual item. Additionally, $71 \%$ admitted that reading the class material bored them. This finding is particularly significant considering previously cited research that indicates informational reading can be attractive to older students if they view the information presented to them as authentic and useful in reaching their goals (Kamil, 2003; Shanahan, 2004). However, only $30 \%$ of these seniors report they preferred to read books that explain interesting facts over books that have story lines with characters and plot, suggesting a general dislike for informational reading as opposed to narrative reading.

\section{Teacher Interviews}

The three teachers involved in this study were interviewed at the conclusion of the nine-week study period. Although two of the teachers had taught for over a ten-year period, one of these instructors was a student teacher. Despite the differences in the amount of experience each teacher had in the classroom, all three responded in surprisingly similar ways on each of the interview questions. Following is a summary of teacher responses to each of the seven interview questions located in Appendix B.

Question 1: Do you think your students like to do class reading? All three teachers replied negatively to this question with two of the instructors qualifying their response with "most" and "the majority don't." Teacher A said she thought students have been "conditioned" to view reading as "drudgery." She also commented that she thought students' dislike of class reading had to do with students viewing textbooks as just "free facts and figures that don't really have a narrative or personal 
experiences woven into them." Teacher B noted that students were more "into electronic media" as opposed to print reading. However, Teacher A said that she believed students only read for information online when they had to and offered research papers as an example. She noted that students primarily used the Internet for gaming or social networking. The student teacher, Teacher $\mathrm{C}$, said he gave students worksheets accompanying their reading: "I think if I just told them to read the textbook for 20 minutes they would just sit there and stare at their desk for 20 minutes."

Question 2: Do you feel confident that students understand what they read in your class? Teacher B reported that he felt confident about class reading because the reading was addressed instructionally in three different ways: the students were supposed to read the material themselves, he always lectured over the reading in class, and finally he asked students to respond to questions about the reading in a worksheet guide. The student teacher, Teacher C, also said he supplemented student silent reading with a worksheet as well. However, he called the worksheet "the best case scenario" for student reading because "they'll skim through the text and pull all the answers, but I don't think they even actually read it then." Teacher A also said she utilized a type of worksheet reading guide when she assigned content text reading but called this practice a "double-edged sword" because students were not actually reading the material, simply cherry-picking answers. None of the three teachers explored student ability to read for content without the use of a worksheet guide. Teachers said they did not really account for student reading outside of the guiding worksheet questions.

Question 3: How do you feel about allowing students time to read in class? Two of the three teachers said they were reluctant to give students time to read in class. Teacher B said he simply could not allot 20-30 minutes for students to do course reading each class period even given the school scheduling of 90 minute block periods: "I wish I had the time to do it (cover course content) all... I'm trying to figure out a way to do this (allow student reading) in my curriculum next year but I don't know." Teacher C commented that it is "tough" to give up 20-30 minutes for "seat work" like student reading. Teacher C also noted that with students doing independent, silent reading there was "less interaction time" with students. Teacher A said she does allow time for students to do some textbook reading and to read articles she occasionally brings to class related to the topic they are studying in American Government.

Question 4 \& 5: What do you think about the class textbook? Do you utilize other trade books as reading supplements for your class? All three teachers acknowledged they did not supplement the textbook reading with other books or kinds of literacy much at all. Teacher A said she sometimes gave students relevant newspaper or magazine articles she came across either in print or online. But this happened only occasionally. Teacher B admitted there were reading resources "out there" he was not utilizing for his class. Teacher C said he was not a "big reader" himself, though he liked reading history. Two of the three civics teachers said they really liked the class government textbook. Also, time was a large issue for two of the teachers. Where would they find the time to allow students to do extra reading in the content area? One of these instructors also expressed apprehension about going beyond prescribed curriculum as supplemental book reading may not be "state standards-based."

Question 6 \& 7: Has there been professional development in literacy in your school? Are you familiar with any reading strategies and do you utilize these? Teacher A said that her school had never had any professional development on adolescent 
reading or application of reading strategies teachers could use in content classes. She theorized the district chose to spend time and money training teachers in the implementation of new programs such as "PLC" (Professional Learning Communities) and "RTI" (Response to Intervention) as opposed to improving general pedagogical skills like how to teach reading. Teacher B seem to agree when interviewed, saying that "specific training sessions on reading techniques and how to incorporate reading into our lessons is more of a superficial type of thing." Teacher C was aware of certain reading strategies that he could use to help his students read better. He said he knew about the "KWL" reading strategy because he had taken a class in college called "reading in the content area"; however, he thought this class was "a big waste of time" because it was mostly about teaching elementary reading skills.

\section{Discussion}

\section{Limitations}

We wanted to explore the topic of high school seniors' academic reading attitudes, searching for potential keys to students' reading proficiency. In order to accomplish this we used multiple measures examining this issue in more than one way and from both student and teacher perspectives. Therefore, we analyzed not only student responses to open-ended questions and survey data, but also teacher interview responses.

We knew a variety of measures such as this would provide us with a rich store of data, but also that managing this amount of information would necessarily limit our study population. Thus, our study sample of 64 students is relatively small. Breaking down open-ended question responses, particularly in a larger study population, searching for repeating conceits, may have proved difficult. Additionally, this student sample was self-selected and self-reported, both potentially problematic in any study. However, we felt that the triangulation effect resultant from a study design utilizing both student and teacher data helped mitigate hyper-inflated responses and other inaccuracies predicated on individual or group subjectivity. One last student consideration is that participants in our study were a month away from graduating, which potentially could have affected responses.

Finally, a mitigating factor in this study was that the survey instrument was selfconstructed. Although there are many reading inventories already published and available for use, a great deal of these have to do mostly with student preferences, "likes" and "dislikes" related to recreational reading. We wanted to develop an instrument that probed into student attitudes towards specifically academic, informational reading and seniors' experience of reading for class. We also wanted to question students about perceptions related to their teachers' reading instruction.

\section{Trapped in a Reciprocal Cycle of Low Reading Expectations}

The apparent contradictions between overt support for class reading combined with non-reading behaviors and a dearth of reading instruction reported from students and teachers suggest a conflicted situation where, although in theory reading may be an established part of the secondary curriculum, in practice and in reality, it is not. The façade that reading is important and happening in the classroom seems to be not only masking but also enabling a perpetuating cycle of low reading expectations between teachers and students. What is particularly confounding is that the perpetuating aspect of this relationship model suggests change or movement away from low reading expectations may be difficult. This type of attitudinal construct has been previously mentioned and described in Bandura's (1978) reciprocal determinism framework. 
Study findings illuminate the reciprocating effects of teacher and student influences on reading instruction. The power of teacher attitudes to affect student reading behaviors is suggested when over half (54\%) of the 64 senior participants respond positively that they believe at least some of their teachers do not really expect them to perform reading assignments. Student influence on teacher reading instruction can be seen in the way teachers are forced to manage student reading in order to safeguard content delivery, relying on contrivances like the "ping-pong" worksheets noted in the literature review (Irvin, Buehl, \& Klemp, 2007). Such practices suggest an instructional reaction to student behaviors. Teacher B discussed the weight of student influences on reading instruction saying, "You have a (class reading) plan, but um, you know, teaching (students) is a constant process of evaluating what you do." Ironically, Teacher B's response indicates he feels some justification for responding to the negative feedback students gave him about reading assignments because reflective practitioners should be flexible and responsive to student preferences. Thus, student attitudes can and apparently do trump curricular mandates.

Although Bandura's cycle is by nature and definition reciprocal, and therefore has the appearance of equally balanced attitudinal forces between teacher and student, we cannot overlook the fact that the teacher's instructional role is, of course, the central relational driver. For example, the most significant area of agreement on the survey was senior high school students' desire to have reading choice, and yet all three government teachers reported in interviews their reliance on a single textbook. Teacher textbook reliance was noted as a problem in the literature review (Daniels \& Zemelman, 2004), and the teachers in this study proved no exception to these research findings with responses that indicated they were either unaware or uninvolved with content reading outside the text. Teacher B said, "Oh, I know there's stuff (content related reading) out there." Thus, teachers chose to be nonresponsive to student influences asking for reading choice and, for this facet of instruction at least, revealed independent instructional control.

Why teachers might choose the area of "reading choice" to step away from student influence and Bandura's model is unclear. It could be, as Teacher B just acknowledged, that they were simply unaware of pertinent content reading outside the text. Other research suggests that some teachers may not have an appreciation or habit of wide reading (Lesley, Watson, \& Elliot, 2007; Nathanson, Pruslow, \& Levitt, 2008; Powell-Brown, 2003).

We should note that there might be other factors in this study beyond teacher or student attitudinal influences that adversely affect content reading practices in the classroom. Both students and teachers at this high school necessarily relied on print textbooks and limited school computer resources for instruction. In their home environments and elsewhere, adolescents today are increasingly attuned to the digital delivery of reading information as opposed to printed text. Smith and Wilhelm (2002) discussed the "schoolishness" of textbooks and the negative impacts such "artifacts" have on student motivation to read. However, despite these motivational concerns, school districts across the country are struggling to keep up with new technologies and electronic delivery formats. The reality is that though many states have begun to legislate e-books or textbook tablets for their local schools, funding for the infrastructure and the outlay for technology to support such mandates may or may not be forthcoming (Scott, 2012).

\section{Implications and Recommendations}

Although seniors in the study reported confidence about understanding what they read for government class, and when queried made optimistic predictions about 
managing college-level reading, they also reported non-reading behaviors. As noted in the literature review, there is an inherent danger in overly positive self-assessments. Students may not have a true understanding of the level of skill necessary to do critical, informational reading, which is important knowledge that could affect learning and proficiency (Dunning, Heath, \& Suls, 2004).

Interestingly, older students can be fairly accurate in their self-perceptions of proficiencies in subject areas like math or English. The routine feedback of grades and report cards check and inform student self-perceptions in these subject areas (Marsh, Koller, Trautwein, Ludtke, \& Baumert, 2005). However, most secondary curriculums do not include a specific literacy course that focuses on the art and skill of informational reading with scheduled grading and instructional feedback. There are no direct measures of literacy competency or expository reading abilities in most secondary school curriculums, but only inadvertent ones buried in the overall performance expectations under content area classes (ACT College and Career Readiness Report, 2006).

Although informational reading may not have its own content area at the high school level, it is projected to be an area of focus under the Common Core standards assessments and it is a central area of testing for college entrance. Without built-in institutional review, like grades for reading proficiency, students must rely on their instructors to provide support and assessment for this skill. This kind of instructional environment was referred to in the literature review (Duke \& Pearson, 2002; Irvin, Buehl \& Klemp, 2007; Sweet, Guthrie, \& Ng, 1998).

Instructional feedback and monitoring of student reading may enhance students' metacognitive reading skills, helping to break the cycle of low reading expectations and better ground perceptions of class reading proficiencies. The teacher feedback on student reading practices can check misunderstandings about the amount or depth of reading necessary for comprehension. Discussing the link between feedback and accurate self-perceptions of academic skills, Dunning et al. (2004), noted, "if higher quality schools make more efficient use of information and provide more accurate feedback to their pupils, those pupils may become better at judging their own performance" (p. 87).

Other facets of reading instruction may also be part of the solution helping teachers and students move off the track of low reading expectations. Reading strategy instruction encourages students to become more active readers and improves reading comprehension (Pressley, 2004). Thus, utilizing reading strategies may build both confidence and motivation to read in the content classroom. Additionally, as previously mentioned, reading instruction that links class reading to students in meaningful and authentic ways, utilizing student choice, interests, and facility with digital literacies can all prove effective in modifying student attitudes about academic reading (The Council Chronicle, 2007).

\section{Conclusion}

As long as low reading expectations between students and teachers is permitted and maintained, older students' reading skills will not be sufficiently addressed in the classroom. Deconstructing attitudinal forces that are difficult to address because of the non-observable nature of said forces is a first step toward exposing a counterproductive environment for student attainment of academic reading skills. Therefore, it is important that we know more about negative learning loops and how to break through the semblance of normalcy in limited-reading secondary classrooms. What is the character of reciprocating negative reading attitudes and how 
much do they impact student academic reading skills? Can we quantify these effects? Questions like these need to be investigated.

Finally, we cannot expect our high school seniors to be proficient readers if they do not know the meaning of reading proficiency for their grade level. Thus, more research needs to be conducted to address older student perceptions of the level of vocabulary, sustained focus, and meaning-making skills necessary for the kind of academic and informational reading they will encounter increasingly in college or career. The findings in this study suggest that a clear understanding of proficiency expectations has the potential to positively affect both reading behaviors and student motivation to read.

\section{References}

ACT College and Career Readiness Report. (2011). College Readiness. Retrieved from http://www.act.org/ newsroom/releases/view.php?year $=2011 \& \mathrm{p}=1476 \&$ lang $=$ english .

ACT College and Career Readiness Report (2006). Reading between the the lines: What the ACT reveals about college readiness in reading. Retrieved from http://www.act.org/research/policymakers/report/ reading.html.

Allington, R. L. (2002). You can’t learn much from books you can’t read. Educational Leadership, 60(3), 16-22.

Alvermann, D. E., \& Moore, D. W. (1991). Secondary school reading. In R. Barr, M. L. Kamil, P. Mosenthal, \& P. D. Pearson (Eds.), Handbook of reading research: Volume 2 (pp. 951-983). New York: Longman.

Alvermann, D. E., Phelps, S. F., \& Ridgeway, V. G. (2007). Content reading and literacy: Succeeding in today's diverse classrooms. Boston: Pearson.

Bandura, A. (1986). Social Foundations of Thought and Action: A Social Cognitive Theory. Englewood Cliffs, NJ: Prentice Hall.

Bandura, A. (1978). The self system in reciprocal determinism. American Psychologist, 33(4), 344-358.

Birchfield, C. M. \& Sappington, J. (2000). Compliance with required reading assignments. Teaching of Psychology, 27(1), 58-60.

Brozo, W. G. \& Sutton Flynt, E. (2008). Motivating students to read in the content classroom: Six evidencebased principles. The Reading Teacher, 62(2), 172-176.

Clason, D. L. \& Dormody, T. J. (1994). Analyzing data measured by individual Likert-type items. Journal of Agricultural Education, 35(4), 31-35.

Common Core Standards. (2012). Retrieved from: http://www.corestandards.org/ELA-Literacy

Coleman, D. (2011). Race to the top: Bringing the common core to life. Retrieved from: http://usny.nysed. gov/rttt/resources/bringing-the-common-core-to-life.html

Creswell, J. W. (1994). Research design: Qualitative and quantitative approaches. Thousand Oaks, CA: Sage Publications.

Daniels, H., \& Zemelman, S. (2004). Subjects matter: Every teacher's guide to content- area reading. Portsmouth, NH: Heinemann.

Donahue, D. (2003). Reading across the great divide: English and math teachers apprentice one another as readers. Journal of Adolescent \& Adult Literacy, 47(1), 24-38.

Duke, N. K. \& Pearson, P. D. (2002). Effective practices for developing reading comprehension. In A. E. Farstrup \& S. J. Samuels (Eds.), What research has to say about reading instruction (pp. 205-242). Newark, DE: International Reading Association.

Dunning, D., Heath, C., \& Suls, J. (2004). Flawed self-assessment. Psychological Science in the Public Interest, 5, 69-106.

Fisher, D. (2004). Setting the "opportunity to read" standard: Resuscitating the SSR program in an urban high school. Journal of Adolescent and Adult Literacy, 48(2), 138-150.

Guthrie, J. T., McRae, A., \& Klauda, S. L. (2007). Contributions of concept-oriented reading instruction to knowledge about interventions for motivations in reading. Educational Psychologist, 42(4), 237-250.

Hacker, D., Bol, L., Horgan, D. \& Rakow, E. (2000). Test prediction and performance in the classroom context. Journal of Educational Psychology, 92, 160-170.

Irvin, J. L., Buehl, D. R., \& Klemp, R. M. (2007). Reading and the high school student. Boston: Pearson Press.

Jacobs, V. A. (2008). Adolescent literacy: Putting the crisis in context. Harvard Educational Review, 78(1), 7-39.

Kamil, M. (2003). Adolescents and literacy: Reading for the $21^{\text {st }}$ century. Retrieved from http://www.all4ed.org

Lee, C. D. \& Spratley, A. (2010). Reading in the disciplines: The Challenge of adolescent literacy. New York: Carnegie Corporation Council on Advancing Adolescent Literacy. Retrieved from http://carnegie.org/ fileadmin/Media/Publications/PDF/tta_Lee.pdf

Lesley, M., Watson, P., \& Elliot, S. (2007). "School” reading and multiple texts: Examining the metacognitive level of secondary-level preservice teachers. Journal of Adolescent \& Adult Literacy, 51(2), 150-162.

Marsh, Herbert W., Koller, Olaf, Trautwein, Ulrich, Ludtke, Oliver, \& Baumert, Jurgen, (2005). Academic self-concept, interest, grades, and standardized test scores: reciprocal effects models of causal ordering. Child Development, 76(2), 397-416. 
McClenaghan, W. A. (2007). Magruder's American government. Upper Saddle River, NJ: Prentice Hall.

McCoach, B. D. \& Siegle, D. (2001). A comparison of high achievers' and low achievers' attitudes, perceptions, and motivations. Academic Exchange Quarterly, 5(2), 71-76.

McNamara, C. (2009). General guidelines for conducting interviews. Retrieved from http://managementhelp. org/evaluatn/intrview.htm

Mitchell, T. L. \& Ley, T. C. (1996). The reading attitudes and behaviors of high school students. Reading Psychology: An International Quarterly, 17, 65-92.

Moss, B., \& Newton, E. (2002). An examination of the informational text genre in basal readers. Reading Psychology, 23(1), 1-13.

Mullis, I. V. S., Martin, M. O., Kennedy, A. M., \& Foy, P. (2007). PIRLS 2006 International Report: IEA's progress in international literacy study in primary schools in 40 countries. Boston: TIMMS and PIRLS International Study Center, Lynch School of Education, Boston College.

Nathanson, S., Pruslow, J., \& Levitt, R. (2008). The reading habits and literacy attitudes of inservice and prospective teachers: Results of a questionnaire survey. Journal of Teacher Education, 59(4), 313-322.

Ness, M. (2007). Reading comprehension Reading comprehension strategies in secondary content-area classrooms. Phi Delta Kappan, 89(3), 229-232.

O’Brien, D. G., S., R. A., \& Moje, E. (1995). Why content literacy is difficult to infuse into the secondary school: Complexities of curriculum, pedagogy, and school culture. Reading Research Quarterly, 30, 442-463.

Powell-Brown, A. (2003-2004). Can you be a teacher of literacy if you don't love to read? Journal of Adolescent \& Adult Literacy, 47, 284-288.

Pressley, M. (2004). The need for research in secondary literacy education. In T. L. Jetton \& J. A. Dole (Eds.), Adolescent literacy research and practice (pp. 415-432). New York: The Guilford Press.

Rieck, B. J. (1977). How content teachers telegraph messages against reading. Journal of Reading, 8, $646-648$.

Schoenbach, R., Braunger, J., Greenleaf, C. \& Litman. C. (2003). Apprenticing adolescents to reading in subject-area classrooms. Phi Delta Kappan, 85(2), 133-138.

Schoenbach, R. \& Greenleaf, C. (2009). Fostering adolescents' engaged academic literacy. In Leila Christenbury, Randy Bomer, \& Peter Smagorinsky (Eds.), Handbook of adolescent literacy research (pp. 98-112). New York: The Guilford Press.

Scott, D. (2012). States continue plugging into digital textbooks. Governing view. Retrieved from: http:// www.governing.com

Shanahan, C. (2004). Teaching science through literacy. In T. L. Jetton \& J. A. Dole (Eds.), Adolescent literacy research and practice, (pp. 75-93). New York: The Guilford Press.

Simpson, M. L., \& Nist, S. L. (2003). An update on strategic learning: It's more than textbook reading strategies. In N. A. Stahl \& H. Boylan (Eds.), Teaching developmental reading: Historical, theoretical, and practical background readings (pp. 157-178). Boston: Bedford/St. Martin's.

Smith, M. W. \& Wilhelm, J. D. (2002). Reading don't fix no Chevys: Literacy in the lives of young men. Portsmouth, NH: Heinemann.

Sweet, A. P., Guthrie, J. T., \& Ng, M. M. (1998). Teacher perceptions and student reading motivation. Journal of Educational Psychology, 90(2), 210-225.

The Council Chronicle. (2007). A policy research brief on adolescent literacy. Retrieved from http://www. ncte.org

The Nation's Report Card. (2011). NAEP 2008 Long Term Trend Report for 17-year-olds. Retrieved from http://www.nationsreportcard.gov

The SAT Report on College and Career Readiness. (2012). Retrieved from http://media.collegeboard.com/ homeOrg/content/pdf/sat-report-college-career-readiness-2012.pdf

Tovani, C. (2004). Do I really have to teach reading? Portland, ME: Stenhouse.

Vacca, R. T. (2006). They can because they think they can. Educational Leadership, 63(5), 56-59. Retrieved from http://www.ascd.org/publications/educational-leadership/feb06/vol63/num05/They-Can-BecauseThey-Think-They-Can.aspx

Wilhelm, J. D. (2007). Engaging readers and writers with inquiry. New York: Scholastic.

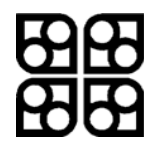


APPENDIX A

Tables 1 and 2 of Study

Table 1: Reading Attitude Open-ended Questions

\begin{tabular}{|c|c|c|c|}
\hline Questions & $\%$ Pos & $\% \mathrm{Neg}$ & $\%$ Ind \\
\hline 1. Are you going to college? & 87 & 13 & \\
\hline $\begin{array}{l}\text { 2. If you are going to college, will you read } \\
\text { everything assigned? How do you see yourself } \\
\text { dealing with college reading? }\end{array}$ & 56 & 37 & 7 \\
\hline $\begin{array}{l}\text { 3. Do you usually do the reading assigned in your } \\
\text { classes? If not, why not? }\end{array}$ & 54 & 45 & 1 \\
\hline $\begin{array}{l}\text { 4. Do you believe it's important to read for class? } \\
\text { Why or why not? }\end{array}$ & 64 & 37 & \\
\hline $\begin{array}{l}\text { 5. Do most of your teachers' give you time to read } \\
\text { in class? Explain. }\end{array}$ & 26 & 74 & \\
\hline $\begin{array}{l}\text { 6. Is reading class materials for } 20 \text { minutes too } \\
\text { long for you? Explain. }\end{array}$ & 45 & 55 & \\
\hline $\begin{array}{l}\text { 7. Have your teachers encouraged you to read } \\
\text { books on your class subject other than the } \\
\text { textbook? Can you name some of those } \\
\text { books or tell about them? }\end{array}$ & 84 & 16 & \\
\hline $\begin{array}{l}\text { 8. Have you had teachers that you felt didn't } \\
\text { expect you to do your reading } \\
\text { assignments? Explain. }\end{array}$ & 54 & 46 & \\
\hline $\begin{array}{l}\text { 9. Have you read an entire book since Christmas } \\
\text { (4 months previous) that was not part of a } \\
\text { classroom assignment? If so, write the title of } \\
\text { the book, author, or what it was about below. }\end{array}$ & 34 & 66 & \\
\hline $\begin{array}{l}\text { 10. When in the all the years you've attended } \\
\text { public school, grades } 1-12 \text {, is a time you } \\
\text { remember reading a lot in school? }\end{array}$ & $\mathrm{n} / \mathrm{a}$ & $\mathrm{n} / \mathrm{a}$ & \\
\hline
\end{tabular}

Note. Pos $=$ positive, Neg $=$ negative, Ind $=$ indeterminate, $\mathrm{n} / \mathrm{a}=$ not applicable 
Trapped in a Cycle of Low Expectations

Table 2: Reading Attitude Survey Subset Items and Statistical Descriptives

\begin{tabular}{|c|c|c|c|c|}
\hline Thematic Subset & $\begin{array}{c}\% \\
\text { S/Agree }\end{array}$ & $\mathrm{n}$ & $\begin{array}{c}\mathrm{m} \\
\text { (S.D.) }\end{array}$ & $\begin{array}{l}\text { Cronbach’s } \\
\text { Alpha }\end{array}$ \\
\hline 1-Reading Identity & & 63 & $\begin{array}{l}2.66 \\
(.50)\end{array}$ & .751 \\
\hline $\begin{array}{l}\text { - I really wouldn't understand the } \\
\text { lesson if reading was the only way } \\
\text { to learn it (reverse code). }\end{array}$ & 58 & & & \\
\hline $\begin{array}{l}\text { - I'm not a very good reader } \\
\text { (reverse code). }\end{array}$ & 41 & & & \\
\hline $\begin{array}{l}\text { - If I read about something, I remember } \\
\text { it better. }\end{array}$ & 64 & & & \\
\hline $\begin{array}{l}\text { - When I read the lesson, I feel confident } \\
\text { that I "get" what the lesson is about. }\end{array}$ & 70 & & & \\
\hline - I think I'm a good reader. & 62 & & & \\
\hline 2-Reading Autonomy & & 63 & $\begin{array}{l}2.51 \\
(.50)\end{array}$ & .711 \\
\hline $\begin{array}{l}\text { - I'd rather read about our lesson topic } \\
\text { myself, than have my teacher lecture } \\
\text { about the reading. }\end{array}$ & 35 & & & \\
\hline - I enjoy reading. & 49 & & & \\
\hline $\begin{array}{l}\text { - I prefer to read what I choose over } \\
\text { reading a single classroom textbook. }\end{array}$ & 85 & & & \\
\hline $\begin{array}{l}\text { - I like reading by myself without } \\
\text { interruptions from the teacher. }\end{array}$ & 67 & & & \\
\hline - I don’t really like to read (reverse code). & 58 & & & \\
\hline $\begin{array}{l}\text { - Rather than me reading the lesson } \\
\text { on my own, I'd prefer the teacher tell } \\
\text { us what's important to know in the } \\
\text { lesson (reverse code). }\end{array}$ & 80 & & & \\
\hline 3-Reading Comprehension & & 63 & $\begin{array}{l}2.66 \\
(.46)\end{array}$ & .685 \\
\hline $\begin{array}{l}\text { - I think I understand most of the } \\
\text { vocabulary in our textbook. }\end{array}$ & 73 & & & \\
\hline $\begin{array}{l}\text { - I actually understand the lesson better } \\
\text { when I do the reading for it. }\end{array}$ & 67 & & & \\
\hline $\begin{array}{l}\text { - Reading the books and materials for } \\
\text { this class is hard for me (reverse code). }\end{array}$ & 24 & & & \\
\hline $\begin{array}{l}\text { - If I knew what some of the words } \\
\text { meant in the textbook more, I could } \\
\text { read it better (reverse code). }\end{array}$ & 73 & & & \\
\hline $\begin{array}{l}\text { - A lot of the time, I'm not really } \\
\text { sure what my reading is about } \\
\text { (reverse code). }\end{array}$ & 45 & & & \\
\hline
\end{tabular}

Continued on next page 
Table 2: Continued

\begin{tabular}{|c|c|c|c|c|}
\hline Thematic Subset & $\begin{array}{c}\% \\
\text { S/Agree }\end{array}$ & $\mathrm{n}$ & $\begin{array}{c}\mathrm{m} \\
\text { (S.D.) }\end{array}$ & $\begin{array}{l}\text { Cronbach's } \\
\text { Alpha }\end{array}$ \\
\hline 4-Content Reading Enjoyment & & 63 & $\begin{array}{l}2.17 \\
(.38)\end{array}$ & .711 \\
\hline $\begin{array}{l}\text { - I think I will check out more books } \\
\text { on our class subject. }\end{array}$ & 11 & & & \\
\hline $\begin{array}{l}\text { - This class makes me want to read more } \\
\text { about the subject. }\end{array}$ & 16 & & & \\
\hline $\begin{array}{l}\text { - I prefer reading books that explain } \\
\text { interesting facts, than books that } \\
\text { have a story line with characters } \\
\text { and a plot. }\end{array}$ & 30 & & & \\
\hline $\begin{array}{l}\text { - Reading this class material bores me } \\
\text { (reverse code). }\end{array}$ & 71 & & & \\
\hline $\begin{array}{l}\text {-There are some really interesting books } \\
\text { on this subject. }\end{array}$ & 62 & & & \\
\hline $\begin{array}{l}\text { - Doing a lot of reading for this class } \\
\text { does not make me more interested } \\
\text { in the subject (reverse code). }\end{array}$ & 80 & & & \\
\hline
\end{tabular}

\section{APPENDIX B}

Teacher Interview Questions

Do you think your students like to read? Please explain.

Do you feel confident that students understand what they read in your class? Please explain.

How do you feel about allowing students time to read in class?

What do you think about the class textbook?

Do you feel like you have a good familiarity with trade books and reading materials other than the class textbook for your students to read in American Government?

Has there been professional development in your school to support content reading? Are you familiar with any reading strategies and do you utilize these to support students as they do their reading assignments for your class? 